\title{
Association between Active Helicobacter pylori Infection and Glaucoma: A Systematic Review and Meta-Analysis
}

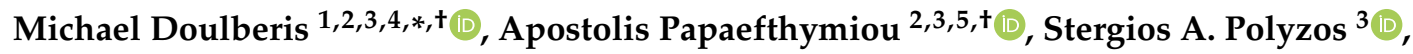 \\ Panagiotis Bargiotas ${ }^{6}\left(\mathbb{0}\right.$, Christos Liatsos ${ }^{7} \mathbb{}$, David Shiva Srivastava ${ }^{4}$, Christos Zavos ${ }^{2}$, \\ Panagiotis Katsinelos ${ }^{2}$ and Jannis Kountouras ${ }^{2, *}$ \\ 1 Division of Gastroenterology and Hepatology, Medical University Department, Kantonsspital Aarau, \\ 5001 Aarau, Switzerland \\ 2 Department of Internal Medicine, Second Medical Clinic, Ippokration Hospital, Aristotle University of \\ Thessaloniki, 54642 Thessaloniki, Macedonia, Greece; appapaef@hotmail.com (A.P.); \\ czavos@ymail.com (C.Z.); akis_katsinelos@yahoo.gr (P.K.) \\ 3 First Laboratory of Pharmacology, School of Medicine, Aristotle University of Thessaloniki, \\ 55134 Thessaloniki, Macedonia, Greece; spolyzos@auth.gr \\ 4 Department of Emergency Medicine, University Hospital Inselspital Bern, Bern, 3010 Bern, Switzerland; \\ davidshiva.srivastava@insel.ch \\ 5 Department of Gastroenterology, University Hospital of Larissa, 41110 Larissa, Greece \\ 6 Department of Neurology, Medical School, University of Cyprus, Nicosia 2029, Cyprus; \\ bargiotas.panagiotis@ucy.ac.cy \\ 7 Department of Gastroenterology, 401 General Military Hospital of Athens, 11525 Athens, Greece; \\ cliatsos@yahoo.com \\ * Correspondence: doulberis@gmail.com (M.D.); jannis@auth.gr (J.K.); Tel.: +30-2310-892238 (J.K.) \\ + These authors have contributed equally and share the first position.
}

Received: 11 May 2020; Accepted: 12 June 2020; Published: 13 June 2020

Abstract: Background: Glaucoma is the second most common cause of blindness worldwide affecting almost 70 million individuals. Helicobacter pylori (H. pylori) is a widespread pathogen with systematic pathogenicity. This meta-analysis aimed to estimate the contradictory data regarding a potential association between active H. pylori infection and glaucoma. Materials and Methods: A research in MEDLINE/PubMed and Google Scholar was conducted and original studies investigating the relationship between $H$. pylori infection and glaucoma were included. Analysis was performed with random effects model. The main outcome was the odds ratio (OR) with $95 \%$ confidence intervals (CI) of H. pylori infection as a risk factor for glaucoma. A parallel analysis studied the role of active infection as indicated by histology and the titer of anti-H. pylori antibodies. For the anti-H. pylori antibody titers, weighted mean differences (WMD) were estimated between patients and controls. Results: Fifteen studies were included, with 2664 participants (872 patients with glaucoma and 1792 controls), divided into primary open-angle glaucoma (POAG), normal tension glaucoma (NTG) and pseudo-exfoliation glaucoma (PEG). The association between $H$. pylori infection and overall glaucoma was significant $(\mathrm{OR}=2.08, \mathrm{CI} 95 \% 1.48-2.93)$ with moderate heterogeneity $\left(I^{2}=61.54 \%\right)$. After stratification by glaucoma subtype, heterogeneity was eliminated in the NTG subgroup. Studies with healthy controls, and controls with anemia yielded very low or no heterogeneity, respectively. Gastric biopsy to document active H. pylori infection yielded the highest OR (5.4, CI: 3.17-9.2, $p<0.001$ ) and null heterogeneity. For anti-H. pylori antibody titers, there was a significant difference in WMD between patients and controls (WMD $15.98 \mathrm{IU} / \mathrm{mL}$; 95\% CI: 4.09-27.87; $p=0.008$ ); values were greater in glaucoma patients, with high heterogeneity $\left(I^{2}: 93.8 \%\right)$. Meta-regression analysis showed that mean age had a significant impact on glaucoma $(p=0.037)$. Conclusions: Active H. pylori infection may be associated with glaucoma with null heterogeneity, as, beyond histology, quantified by anti-H. pylori titers and increases with age. 
Keywords: Helicobacter pylori infection; glaucoma; primary open-angle glaucoma; pseudo-exfoliation glaucoma

\section{Introduction}

Helicobacter pylori (H. pylori) is a Gram-negative spiral-shaped bacterium [1] with worldwide distribution. About $58 \%$ (varying from 39.9-91.7\%) of the global population is estimated to be colonized with $H$. pylori and its prevalence is even higher in less-industrialized countries [2-4]. H. pylori can cause chronic gastritis, peptic ulcers, gastric adenocarcinoma, as well as mucosa-associated lymphoid tissue lymphoma [5-10]. Beyond this local pathogenicity, there appears to be a variety of $H$. pylori-associated extragastric manifestations [11-14], including Alzheimer's disease (AD), primary open-angle glaucoma (POAG), also called "ocular AD" and pseudoexfoliative glaucoma (PEG) at least in certain populations. Glaucoma, leads to the death of retinal ganglion cells and their axons and is the second most frequent cause of blindness worldwide. It affects 66.8 million individuals, causes bilateral blindness in 6.7 million people [15-17], and is a neurodegenerative disorder of the optic nerve, with the hallmark of increasing "cupping" of the optic disc [18].

Studies evaluating the potential relationship between $H$. pylori infection and POAG have reported either positive or no association, so that there is still controversy. A conceivable explanation of this discrepancy is that the serological test used by several studies does not discriminate between active and past infections [19-24]. It is important to note that only active $H$. pylori infection induces humoral and cellular immune responses that, due to molecular mimicry, cross-react with components of host nerves, thereby inducing apoptotic injury to extragastric tissues and may contribute to the pathophysiology of certain pathologies such as Guillain-Barré syndrome [25-27] and autoimmune pancreatitis [28-30] and possibly in glaucoma [6,31,32] or other neurodegenerative disorders [33-35]. As a potential exception, high anti-H. pylori Immunoglobulin (Ig)G titers appear to be associated with the degree of gastritis and mucosal bacterial concentration [36]; anti-H. pylori titer is associated with the gastric bacterial burden; and major reductions in $\mathrm{H}$. pylori infiltration and serum anti-H. pylori titers are recorded after H. pylori eradication [37]. Thus, the serum high anti-H. pylori titer might be an index of H. pylori load in patients with active infection.

We were motivated by these controversies to conduct a systematic review and meta-analysis of observational studies, in order to evaluate the association between glaucoma and active $H$. pylori infection documented by gastric biopsy. We also investigated whether the titer of serum anti-H. pylori IgG antibodies was associated with glaucoma.

\section{Methods}

\subsection{Strategy of Bibliographic Search}

The study protocol was in accordance with the reporting guidelines for the Meta-analysis of Observational Studies in Epidemiology (MOOSE) [38]. The search strategy and flowchart (Figure 1) were performed according to the Preferred Reporting Items for Systematic Reviews and Meta-Analyses (PRISMA) [39]. An initial online search was confined to English language literature from 1 January 1960 to 30 September 2019. The search queries included the following Boolean search terms, modified according to the demands of each database; "Helicobacter pylori" OR "H. pylori" OR Hp OR "Campylobacter pylori") AND (glaucoma OR "open-angle glaucoma" OR "primary open-angle glaucoma" OR POAG OR "ocular hypertension" OR "pseudo-exfoliation glaucoma"). We searched the MEDLINE/PubMed and Google Scholar databases. Furthermore, additional relevant articles were searched in the reference lists of the retrieved articles, as well as by using the "similar article" function of PubMed. Unpublished works, abstracts, and oral or poster presentations were excluded. If we required additional data, e-mails were sent to the first and/or the corresponding authors. A database 
of all retrieved articles was created and managed with the reference manager Mendeley Desktop for Windows v. 1.19.1 (Mendeley Ltd., Elsevier, Amsterdam, The Netherlands).

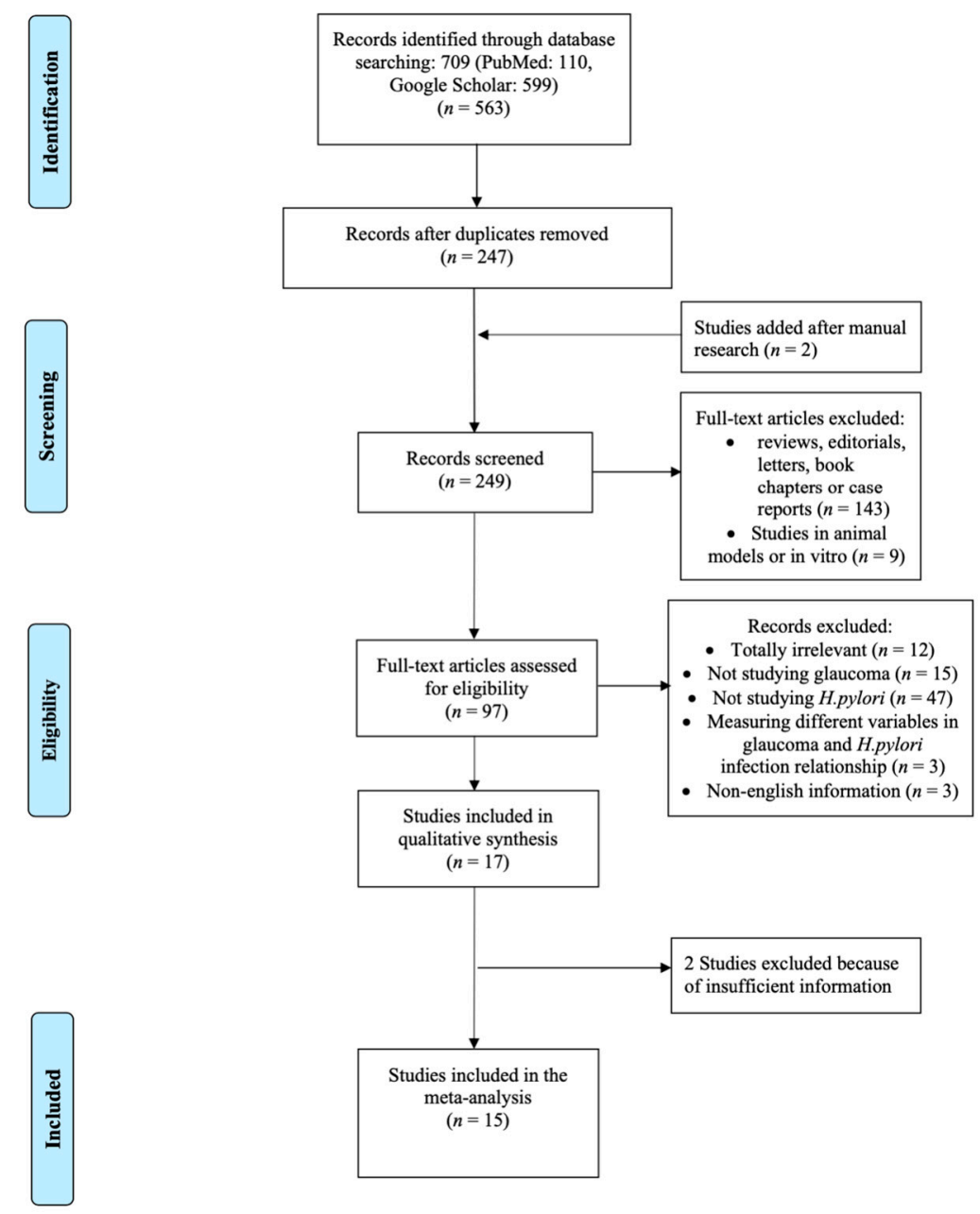

Figure 1. Flowchart based on Preferred Reporting Items for Systematic Reviews and Meta-Analyses (PRISMA) guidelines interpreting the selection process of the reviewed studies to insert in the meta-analysis.

\subsection{Inclusion-Exclusion Criteria}

Original, full-text observational studies were included (cross-sectional, case-control or cohort studies).

Studies were excluded if: the diagnosis of glaucoma was not clearly stated; the diagnosis of H. pylori infection was biased (e.g., patients recently treated with antibiotics or proton pump inhibitors); the data included incomplete and/or the corresponding author did not provide additional records; the publications did not contain original data, (e.g., letters to the editor, editorials, commentaries, reviews, meta-analyses); or if they evaluated fewer than seven points in the quality assessment process using the Newcastle-Ottawa scale (NOS).

The control groups of all studies were assessed and the least-acceptable conditions were the absence of glaucoma-related ocular diseases, or H. pylori-related gastric diseases (dyspepsia, peptic ulcer, gastric cancer, mucosa-associated lymphoid tissue lymphoma) and major co-morbidities (such as cancer, liver cirrhosis and cardiovascular or renal failure). 


\subsection{Data Extraction and Assessment for Study Quality}

Two investigators (M.D. and A.P.) independently first reviewed the title and abstract of the retrieved studies. After this initial screening, they evaluated the content of the full text of the remaining articles and their quality. If a disagreement emerged, this was resolved by the senior investigator (J.K.) and then a joint review was performed, in order to reach consensus. If there was more than one article on a single study (implying potential patient overlap), the most recent publication was included in the meta-analysis.

Information was then extracted into the electronic database, as follows: (1) first author's name, type of study, journal and year of publication; (2) country of origin and race, patient and control numbers and their mean age; (3) method of $H$. pylori infection diagnosis; (4) final outcomes expressed in odds ratio (OR). An individual file was created for studies that calculated the anti-H. pylori titers and all medians and standard deviations (SD) were additionally extracted for both groups.

\subsection{Quality Assessment}

The quality of the included studies was assessed by using the Newcastle-Ottawa scale (Ottawa Hospital Research Institute, Ottawa, ON, Canada) [40]. In cases of conflicting ratings between the two reviewers (M.D. and A.P.), the arbitration of J.K. was required.

\subsection{Outcomes}

The association between $H$. pylori infection and glaucoma patients and controls was expressed by OR (95\% confidence intervals (CI)). To assess potential heterogeneity, subgroup analysis and meta-regression analysis were conducted. Weighted mean differences (WMD) were used to evaluate differences in anti-H. pylori antibody titers between patients and controls.

\subsection{Statistical Analysis}

All statistical analyses were performed with STATA v.14.0 software for OSX (Stata Corp., College Station, TX, USA). The fundamental inserted commands included "metan", "metareg", "metafunnel" and "metabias".

As heterogeneity among the studies was suspected, a random effect model was implemented. The heterogeneity among the analyzed studies was evaluated by three tools; the $\tau^{2}$ test, the $\chi^{2}$ test and $I^{2}$. If the $Q$ value exceeded the degrees of freedom with $p<0.05$, heterogeneity was consistent [41]. Subgroup analyses were performed to investigate potential factors causing heterogeneity by evaluating the effect of independent categorical variables (i.e., race, glaucoma subtype, H. pylori infection diagnostic method). Likewise, meta-regression was performed to estimate the effect of continuous variables (i.e., mean age, male to female ratio, anti-H. pylori antibodies level). For the variable "race", studies originating in Europe and America were included in the "West" group, whereas studies from Asia were in the "East" group and those from Africa in a distinct group.

Anti-H. pylori antibody titers in patients and controls were compared in studies that provided sufficient quantitative information about anti-H. pylori antibody titers that could be inserted into our model $[22,24,34,42]$. Subgroup and meta-regression analyses were applied as previously described.

As the authors have a special interest in extra-gastric manifestations of $H$. pylori infection, this might be associated with specific bias. Therefore, a sensitivity analysis was performed by excluding all studies of our group. Any potential publication bias was examined with Begg's and Egger's tests, with $p<0.05$ in both tests indicating publication bias.

\section{Results}

\subsection{Literature Search and Characteristics of the Studies}

The flowchart according to the PRISMA guidelines is depicted in Figure 1. The initial search yielded a total of 709 articles. After removal of duplicates (462), 247 articles remained for the further 
screening process, which included checking titles and abstracts, followed by reviewing the full text manuscript of the eligible studies $(n=97)$. Eventually 17 studies were included in the systematic review. Two of these were excluded, as extra data were needed and these were not provided by the corresponding authors, and/or the methodology was doubtful $[43,44]$. Therefore, 15 final studies were considered for the meta-analysis and included 2664 participants (872 patients with glaucoma and 1792 controls) with three types of glaucoma (POAG, NTG, PEG) [19,22-24,34,41,42,45-52]. One potential type (ocular hypertension), reported by Galloway et al. [24] was excluded because it did not meet our own inclusion criteria.

Study characteristics and the respective outcomes are shown in Table 1. Most of the studies were carried out in Asia $(n=8)$, followed by Europe $(n=5)$. In Africa and in America, one single study per continent was conducted. Almost half of the included articles were case-control $(n=7)$ and the rest cohort studies.

A final evaluation of the included studies was performed on the basis of the NOS, except for one study, which provided all the necessary information for our analysis in the English abstract, even though the main text was in Persian (Farsi) [50]. All of the evaluated studies met a score of more than seven (7).

The authors of all included studies considered their results separately for each glaucoma subtype and we followed this classification by creating 23 records derived from the 15 studies included. In order to investigate the effect of anti-H. pylori antibody titers on glaucoma, we extracted data from 8 datasets, which clearly provided mean values and standard deviations of this parameter.

\subsection{Overall Results and Subgroup Analyses}

The overall association between $H$. pylori infection and glaucoma was statistically significant $(\mathrm{OR}=2.08, \mathrm{CI} 95 \% 1.48-2.93)$ (Figure $2 \mathrm{a})$. As the heterogeneity was moderately high $\left(I^{2}=61.54 \%\right)$ it was necessary to check for potential cofounders that might possibly have affected the results. We therefore also performed subgroup analysis (Table 2) and meta-regression analysis. After stratification by glaucoma subtype or region, the heterogeneity for each region remained essentially unchanged. There was only a statistically significant reduction in the heterogeneity of the NTG subgroup.

It was investigated whether the control group influenced the results. Studies with cataract controls did not lead to a significant association between $H$. pylori infection and glaucoma. In this subgroup, studies with healthy controls provided acceptable heterogeneity $\left(I^{2}=23.07 \%\right)$, whereas studies with anemia controls yielded null heterogeneity.

It was also investigated whether the results were influenced by the method of $H$. pylori infection detection. Gastric mucosa histology for $\mathrm{H}$. pylori infection documentation [51] gave the highest OR of all methods (5.4, CI: 3.17-9.2, $p<0.001$ ), but also null heterogeneity. By contrast, studies that used the urea breath test (UBT) did not show any significant association between H. pylori infection and glaucoma. Finally, meta-regression analyses did not reveal any benefit of continuously measured variables on the overall outcome and heterogeneity.

Comparison of the WMD of anti-H. pylori antibody titers between patients and controls gave a statistically significant difference (WMD $15.98 \mathrm{IU} / \mathrm{mL}$ ); this was greater in glaucoma patients than in controls, albeit with high heterogeneity ( $p=0.008$, CI: 4.09-27.87, $I^{2}: 93.8 \%$ ) (Figure 2b). Subgroup analysis could not explain the source of the heterogeneity. However, the meta-regression analysis proved that mean age had a statistically significant impact on the results $(p=0.037)$. More specifically, as Figure 2c illustrates, increasing age was associated with greater WMD of anti-H. pylori titers in glaucoma patients than in controls. 
Table 1. The characteristics of the included studies.

\begin{tabular}{|c|c|c|c|c|c|c|c|c|c|c|c|c|c|c|}
\hline No & First Author & $\begin{array}{c}\text { Year of } \\
\text { Publication }\end{array}$ & Type of Study & $\begin{array}{l}\text { Country } \\
\text { (Region) }\end{array}$ & Host Journal & $\begin{array}{c}\text { Glaucoma } \\
\text { Cases }\end{array}$ & Controls & $\begin{array}{l}\text { Mean Age } \\
\text { (years) * }\end{array}$ & $\begin{array}{l}\text { Controls } \\
\text { Deposit }\end{array}$ & $\begin{array}{l}\text { Glaucoma } \\
\text { Subtype }\end{array}$ & $\begin{array}{l}\text { H. pylori Infection } \\
\text { Diagnosis }\end{array}$ & $\begin{array}{l}\text { MD of Anti-H. } \\
\text { pylori Titers }\end{array}$ & $\begin{array}{l}\text { NOS } \\
\text { Score }\end{array}$ & $\begin{array}{c}\text { Relationship between } \mathrm{H} \text {. } \\
\text { pylori and Glaucoma ( } \mathrm{OR}, \mathrm{Cl})\end{array}$ \\
\hline 1 & Abrishami et al. & 2007 & Cohort & Iran (East) & Віпа J Ophthalmol & 44 & 79 & 60.8 & Cataract & POAG & ELISA & N/A & $\mathrm{N} / \mathrm{A}$ & $3.69(1.68-8.13)$ \\
\hline 2 & Deshpande et al. & 2008 & Case-control & India (East) & J Glaucoma & 50 & 50 & 63.7 & Cataract & POAG & ELISA & $\begin{array}{l}20^{\prime} 220 \\
8^{\prime} 10\end{array}$ & 8 & $1.20(0.52-2.79)$ \\
\hline $\begin{array}{l}3 \\
4 \\
4\end{array}$ & $\begin{array}{l}\text { Deshpande et al. } \\
\text { Galloway et al. }\end{array}$ & $\begin{array}{l}2008 \\
2003\end{array}$ & $\begin{array}{l}\text { Case-control } \\
\text { Cohort }\end{array}$ & $\begin{array}{c}\text { India (East) } \\
\text { Canada (West) }\end{array}$ & $\begin{array}{c}\text { J Ilaucoma } \\
\text { Ophthalmology }\end{array}$ & $\begin{array}{l}50 \\
38\end{array}$ & $\begin{array}{l}50 \\
94\end{array}$ & $\begin{array}{l}67 \\
63.2\end{array}$ & $\begin{array}{l}\text { Cataract } \\
\text { Healthy }\end{array}$ & $\begin{array}{l}\text { PEG } \\
\text { POAG }\end{array}$ & $\begin{array}{l}\text { ELISA } \\
\text { ELSA }\end{array}$ & & 8 & $\begin{array}{l}0.41(0.18-0.91) \\
141(0.59-34)\end{array}$ \\
\hline${ }_{5}^{4}$ & $\begin{array}{l}\text { Galloway et al. } \\
\text { Galloway et al. }\end{array}$ & $\begin{array}{l}2003 \\
2003\end{array}$ & $\begin{array}{l}\text { Cohort } \\
\text { Cohort }\end{array}$ & $\begin{array}{l}\text { Canada (West) } \\
\text { Canada (West) }\end{array}$ & $\begin{array}{l}\text { Ophthalmology } \\
\text { Ophthalmology }\end{array}$ & $\begin{array}{l}38 \\
16\end{array}$ & $\begin{array}{l}94 \\
94\end{array}$ & $\begin{array}{l}63.2 \\
73.2\end{array}$ & $\begin{array}{l}\text { Heaelthy } \\
\text { Healthy }\end{array}$ & $\begin{array}{l}\text { POAG } \\
\text { PEG }\end{array}$ & $\begin{array}{l}\text { ELISA } \\
\text { ELISA }\end{array}$ & $\begin{array}{l}-10^{-10} 600 \\
18^{\prime} 500\end{array}$ & 8 & $\begin{array}{l}1.41(0.59-3.4) \\
1.32(0.38-4.54)\end{array}$ \\
\hline 6 & Galloway et al. & 2003 & Cohort & Canada (West) & Ophthalmology & $\begin{array}{l}16 \\
19\end{array}$ & $\begin{array}{l}94 \\
94\end{array}$ & $\begin{array}{l}7.2 \\
67.7\end{array}$ & $\begin{array}{l}\text { Heaniny } \\
\text { Healthy }\end{array}$ & NTG & $\begin{array}{l}\text { ELISA } \\
\text { ELISA }\end{array}$ & $\begin{array}{l}18,300 \\
23^{\prime} 300\end{array}$ & & $1.41(0.45-4.4)$ \\
\hline 7 & Hong et al. & 2007 & Case-control & China (East) & Asian J Ophtholmol & 24 & 24 & 63.9 & Healthy & POAG & UBT & $\mathrm{N} / \mathrm{A}$ & 8 & $4.49(1.26-16)$ \\
\hline 8 & Kim et al. & 2011 & $\begin{array}{l}\text { Retrospective } \\
\text { Choort }\end{array}$ & $\begin{array}{l}\text { South Korea } \\
\text { (East) }\end{array}$ & IOVS & 100 & 88 & 55.6 & Healthy & NTG & ELISA & N/A & 8 & $2.05(1.12-3.75)$ \\
\hline 9 & Kim et al. & 2011 & $\begin{array}{l}\text { Retrospective } \\
\text { Cohort }\end{array}$ & $\begin{array}{l}\text { South Korea } \\
\text { (East) }\end{array}$ & IOVS & 104 & 1116 & 53.4 & Healthy & NTG & ELISA & $\mathrm{N} / \mathrm{A}$ & & $1.83(1.17-2.86)$ \\
\hline 10 & Kountouras et al. & 2003 & Cohort & Grece (West) & $\begin{array}{l}\text { Graefé's Arch Clin } \\
\text { Exp phhthalmol }\end{array}$ & 27 & 31 & 70.6 & Cataract & POAG & ELISA & $37^{\prime} 210$ & 8 & $2.35(0.63-8.76)$ \\
\hline 11 & Kountouras et al. & 2003 & Cohort & Greece (West) & $\begin{array}{l}\text { Graefe's Arch Clin } \\
\text { Exp Dhhthalmol }\end{array}$ & 19 & 31 & 69.2 & Cataract & PEG & ELISA & $25^{\prime} 800$ & & $25(1.38-452.34)$ \\
\hline 12 & Kountouras et al. & 2002 & Cohort & Greece (West) & Arch Intern Med & 41 & 30 & 61.4 & Anemia & POAG & $\begin{array}{l}\text { HISTOLOGY } \\
\text { HSTOOYY }\end{array}$ & $18^{\prime} 570$ & 8 & $8.23(2.53-26.75)$ \\
\hline & Kountouras et al. & 2001 & Case-control & Greece (West) & Ophthalmology & 32 & 30 & 64 & Anemia & POAG & HISTOLOGY & $\mathrm{N} / \mathrm{A}$ & & $8(2.25-28.48)$ \\
\hline 14 & Kountouras et al. & 2001 & Case-control & Greece (West) & Ophthalmology & 9 & 30 & 62 & Anemia & PEG & HISTOLOGY & N/A & 7 & $9.14(1.01-82.44)$ \\
\hline 15 & $\begin{array}{l}\text { Kurtz et al. } \\
\text { Kal }\end{array}$ & ${ }^{2008}$ & Colort & $\begin{array}{l}\text { Israel (West) } \\
\text { stest }\end{array}$ & J Ilaucoma & 集2 & 36 & & Cataract & $\begin{array}{l}\text { POAG } \\
\text { POF }\end{array}$ & $\begin{array}{l}\text { ELISA } \\
\text { ELSA }\end{array}$ & N/A & 8 & $0.74(0.21-2.67)$ \\
\hline $\begin{array}{l}16 \\
17\end{array}$ & $\begin{array}{l}\text { Kurtz e tal. } \\
\text { Kurtz tal. }\end{array}$ & $\begin{array}{l}2008 \\
2008\end{array}$ & $\begin{array}{l}\text { Cohort } \\
\text { Cohort }\end{array}$ & $\begin{array}{l}\text { Israel (West) } \\
\text { Israel (West) }\end{array}$ & $\begin{array}{l}\text { IGlaucoma } \\
\text { J Glaucoma }\end{array}$ & $\begin{array}{l}23 \\
15\end{array}$ & $\begin{array}{l}36 \\
36\end{array}$ & 67.7 & $\begin{array}{l}\text { Cataract } \\
\text { Cataract }\end{array}$ & $\begin{array}{l}\text { PEG } \\
\text { NTG }\end{array}$ & $\begin{array}{l}\text { ELSA } \\
\text { ELISA }\end{array}$ & $\begin{array}{l}\mathrm{N} / \mathrm{A} \\
\mathrm{N} / \mathrm{A}\end{array}$ & & $\begin{array}{l}1.19(0.4-3.5 .54) \\
0.96(0.28-3.27)\end{array}$ \\
\hline 18 & Noche et al. & 2016 & Case-control & $\begin{array}{l}\text { Cameroon } \\
\text { (Afican }\end{array}$ & Ophthalmology and & 50 & 31 & 58.52 & Healthy & POAG & ELISA & $\mathrm{N} / \mathrm{A}$ & 8 & $0.42(0.12-1.43)$ \\
\hline 19 & Samarai et al. & 2014 & Case-control & $\begin{array}{l}\text { (Africa) } \\
\text { Iran (East) }\end{array}$ & $\begin{array}{l}\text { Eyy Disenses } \\
\text { Global Journal of }\end{array}$ & 37 & 42 & 73.05 & Anemia & POAG & ELISA & $\mathrm{N} / \mathrm{A}$ & 8 & $5.61(1.68-18.75)$ \\
\hline 20 & Sultana et al. & 2019 & Case-control & Bangladesh & $\begin{array}{l}\text { Health Science } \\
\text { BSMMUI }\end{array}$ & 40 & & 51.4 & Healthy & POAG & Fusa & Nat & 8 & $389(153-987$ \\
\hline 20 & Surtana é tal. & & Case-contror & (East) & $\begin{array}{l}\text { BSINAC) } \\
\text { BMC }\end{array}$ & 40 & to & 0.1 .4 & Fearliny & TOAG & ELISA & N/A & s & $3.89(1.53-9.87)$ \\
\hline 21 & Tsolaki et al. & 2015 & Cohort & Greece (West) & $\begin{array}{l}\text { BMC } \\
\text { hthalmolog }\end{array}$ & 35 & 31 & 62.18 & Healthy & POAG & HISTOLOGY & $\mathrm{N} / \mathrm{A}$ & 7 & $2.65(0.97-7.24)$ \\
\hline 22 & Tuzcu et al. & 2015 & Case-control & Turkey (East) & Arq Bras Oftalmol & 35 & 35 & 59.08 & Healthy & POAG & UBT & N/A & 8 & $1.41(0.55-3.62)$ \\
\hline 23 & Zavos et al. & 2012 & Case-control & Greece (West) & Ophthalmic Res & 51 & 35 & 71.4 & Anemia & POAG & HISTOLOGY & N/A & 8 & $5.69(2.08-15.54)$ \\
\hline
\end{tabular}

${ }^{*}$ refers to glaucoma group, CI; Confidence Interval, ELISA; Enzyme Linked Immunosorbent Assay, H. pylori; Helicobacter pylori, MD; Differences of Means, N/A; not available, NOS;

Newcastle-Ottawa scale, NTG; Normal Tension Glaucoma, OAG; Open Angle Glaucoma. OR; Odds Ratio, PEG; Pseudo-Exfoliation Glaucoma,UBT; urea breath test. 

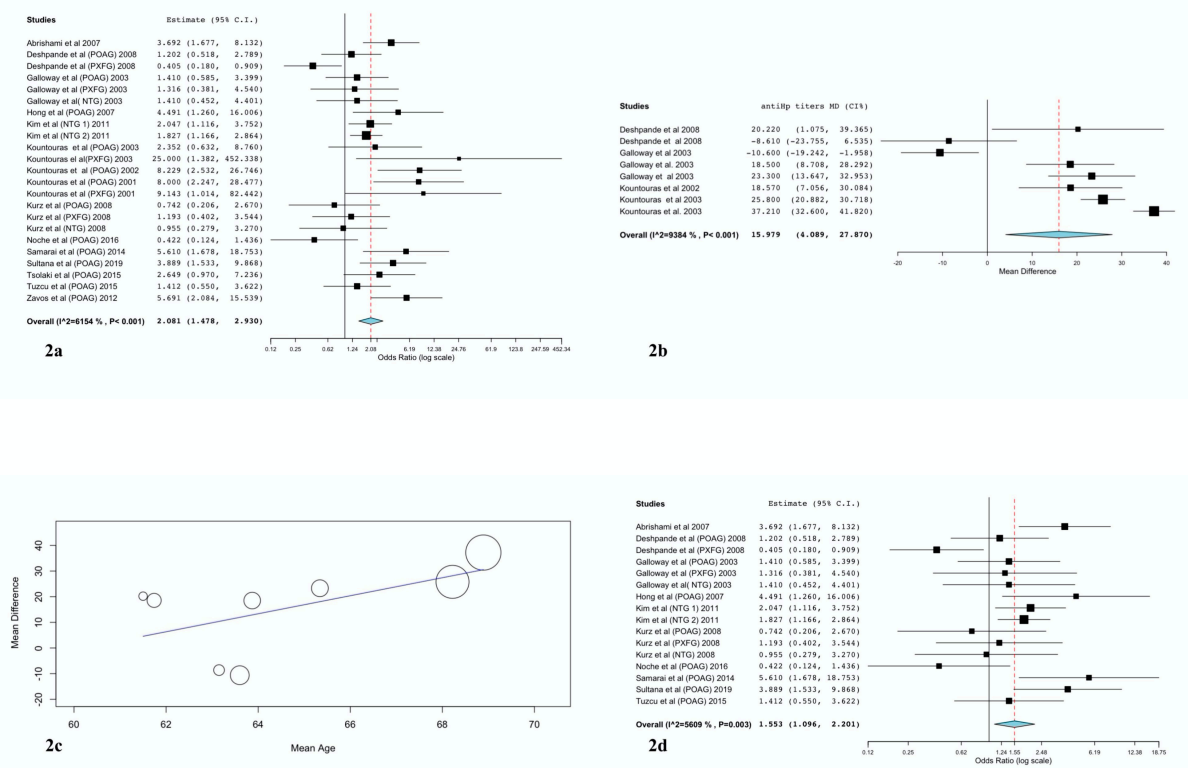

Figure 2. (a) Forest plot illustrating, in OR, the overall and per included study association between H. pylori infection and glaucoma risk. (b) Forest plot for the association between means of difference of anti- H. pylori antibodies titers and glaucoma occurrence. (c) Meta-regression scatter plot indicating the relationship between the means of difference of anti-H. pylori antibodies titers and glaucoma risk after adjustment for mean age. (d) Sensitivity analysis excluding our group's studies and confirming the absence of bias because of our own studies. CI, confidence interval; H. pylori; Helicobacter pylori; NTG, normal tension glaucoma; OR, odds ratio; POAG, primary open angle glaucoma; PEG, pseudo-exfoliation glaucoma; MD, weighted mean differences.

Table 2. Subgroup analysis regarding the relationship between $H$. pylori infection and glaucoma.

\begin{tabular}{|c|c|c|c|c|c|c|c|c|}
\hline \multirow[b]{2}{*}{ Subgroup } & \multirow[b]{2}{*}{ Datasets } & \multicolumn{3}{|c|}{ Random Effects Model } & \multicolumn{4}{|c|}{ Heterogeneity } \\
\hline & & OR & CI 95\% & $p$ & $Q$ & $I^{2}(\%)$ & $t^{2}$ & $p$ \\
\hline Total & 23 & 2.08 & $1.48-2.93$ & $<0.001$ & 57.21 & 61.54 & 0.39 & $<0.001$ \\
\hline \multicolumn{9}{|l|}{ Region } \\
\hline EAST & 8 & 2.1 & $1.23-3.56$ & 0.006 & 25.1 & 72.11 & & $<0.001$ \\
\hline WEST & 14 & 2.32 & $1.47-3.64$ & $<0.001$ & 25.51 & 49.04 & & 0.029 \\
\hline AFRICA & 1 & 0.42 & $0.12-1.44$ & $N / A$ & $N / A$ & $N / A$ & & $N / A$ \\
\hline \multicolumn{9}{|c|}{ Glaucoma Subtype } \\
\hline POAG & 14 & 2.57 & $1.66-3.99$ & $<0.001$ & 31.59 & 58.85 & & 0.003 \\
\hline PEG & 5 & 1.69 & $0.53-5.34$ & 0.373 & 13.68 & 70.76 & & 0.008 \\
\hline NTG & 4 & 1.76 & $1.27-2.46$ & $<0.001$ & 1.36 & 0 & & 0.715 \\
\hline \multicolumn{9}{|l|}{ Study Design } \\
\hline Cohort & 13 & 1.98 & $1.44-2.74$ & 0.141 & 17.24 & 30.4 & & 0.141 \\
\hline Case-control & 10 & 2.33 & $1.13-4.81$ & $<0.001$ & 39.95 & 77.47 & & $<0.001$ \\
\hline \multicolumn{9}{|l|}{ Control groups } \\
\hline Cataract & 8 & 1.37 & $0.7-2.67$ & 0.362 & 20.52 & 65.89 & & 0.005 \\
\hline Anemia & 5 & 6.78 & $3.88-11.83$ & $<0.001$ & 0.45 & 0 & & 0.98 \\
\hline Healthy & 10 & 1.82 & $1.33-2.5$ & $<0.001$ & 11.7 & 23.07 & & 0.231 \\
\hline \multicolumn{9}{|c|}{ H. pylori infection diagnosis } \\
\hline ELISA & 16 & 1.57 & $1.09-2.28$ & 0.017 & 35.35 & 57.57 & & 0.002 \\
\hline UBT & 2 & 2.32 & $0.76-7.13$ & 0.142 & 2.06 & 51.35 & & 0.152 \\
\hline HISTOLOGY & 5 & 5.4 & $3.17-9.2$ & $<0.001$ & 3.02 & 0 & & 0.555 \\
\hline
\end{tabular}

CI; Condifence Interval, elisa Enzyme Linked Immunosorbent Assay, H. pylori; Helicobacter pylori, N/A; not available, NTG; Normal Tension Glaucoma, OAG; Open Angle Glaucoma, OR; Odds Ratio, PEG; Pseudo-Exfoliation Glaucoma, UBT; Urea Breath Test. 


\subsection{Sensitivity Analysis}

We excluded our own studies, and then repeated the analysis (Figure 2d), including 16 datasets. The derived OR (1.55, CI 95\%: 1.1-2.2) indicated a positive relationship between H. pylori infection and glaucoma, with similar heterogeneity to the initial analysis.

\subsection{Publication Bias}

For the association between $H$. pylori infection and glaucoma, Egger and Begg tests provided $p$ values of 0.347 and 0.174 , respectively, thus eliminating the possibility of publication bias (Figure 3). Similarly, for the comparison of the WMD of anti-H. pylori antibody titers between patients and controls, the Egger and Begg tests provided $p$ values 0.266 and 0.107. Nonetheless, despite the non-significant tests, there is a visual asymmetry in the funnel plots, which should be considered.
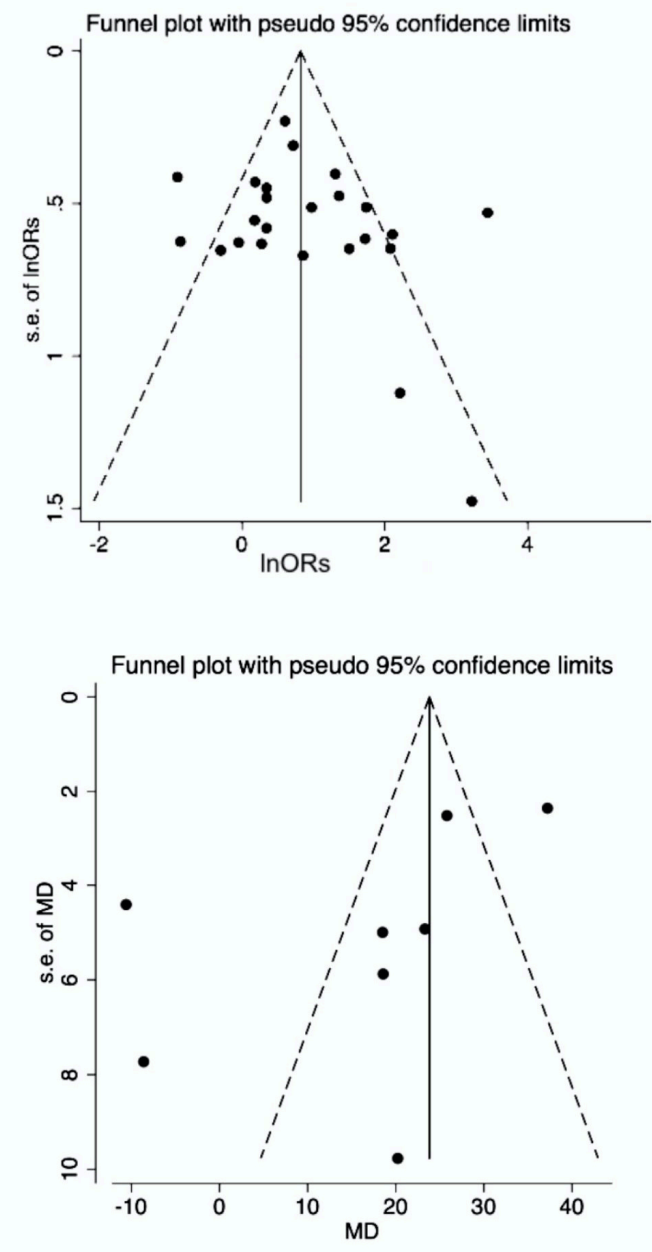

Figure 3. Funnel plot for both study models. Despite the non-significant Egger and Begg tests, there is a visual asymmetry in the funnel plots, indicative of a degree of publication bias. MD; weighted mean differences, OR; odds ratio, SE; standard error.

\section{Discussion}

Glaucoma is a major economic burden, with as many as 80 million patients by $2020[17,53,54]$. To our knowledge, this meta-analysis demonstrated, for the first time, a strong association between glaucoma and active H. pylori infection as documented by histology (Table 2) with total lack of heterogeneity. Relative data indicate that histology displays the higher sensitivity and specificity than the UBT and the rapid urease test (RUT) for the diagnosis of active H. pylori infection $[55,56]$. 
The cited sensitivity and specificity are $80-95 \%$ and $99-100 \%$, respectively [55]. Studies in which H. pylori infection was diagnosed by UBT did not indicate a significant association, although this requires careful interpretation due to the small study number $(n=2)$. Furthermore, the selection of controls seems to affect this association. The association was less robust when cataract patients were used as controls, whereas healthy or anemic controls maintained the positive relationship and yielded low heterogeneity (Table 2). Thus, if histology is to be routinely used for $H$. pylori infection documentation, given its great correlation to the "gold-standard" H. pylori culture and its superiority to the other methods [55,57], further large-scale prospective studies are necessary to confirm this strong association with zero heterogeneity.

Moreover, a novelty of this meta-analysis is the quantification of the aforementioned association between $H$. pylori infection and glaucoma by using the anti- $H$. pylori IgG titer to reflect potentially active $H$. pylori infection; in clinical terms, the higher anti-H. pylori titers, the higher possibility of glaucoma-an association that is strengthened by aging. A possible hypothesis is that aging is simply a common denominator for both $H$. pylori infection and glaucoma. However, mechanistic studies may help to explain how aging mediates this association. Recently, the concept of triggering autoimmune disorders after bacterial infections through antigenic similarities was applied to $H$. pylori infection, thus unraveling the molecular mimicry between $H$. pylori antigens and host proteins-targets of autoantibodies in many conditions [58,59]. In this regard, the decline of the immune system due to aging is reflected in the augmented susceptibility to autoimmune disorders [60-62] and autoimmunity has been postulated to play an important role in glaucomatous injury to the optic nerve, $[31,63,64]$ so that autoantibodies against proteins in retina and/or the optic nerve might be involved in glaucomatous neuropathy of the optic nerve [63,64]. Autoimmune injury to the optic nerve may occur directly by autoantibodies or indirectly by way of a mimicked autoimmune response to a sensitizing antigen, which in turn might damage retinal ganglion cells [63-66]. Autoantibodies against proteins in the retina and/or the optic nerve, resulting from the possible molecular mimicry between $H$. pylori and ocular proteins, might be involved in glaucomatous neuropathy of the optic nerve [63,64]. More specifically, H. pylori antigens stimulate the production of specific antibodies which recognize homologous host protein sequences, such as in glycoproteins, heat-shock proteins (Hsps), $\mathrm{H}^{+} / \mathrm{K}^{+}$ATPase, $\mathrm{H}^{+} / \mathrm{K}^{+}$-adenosine triphosphatase, Human leukocyte antigens (HLA), chemokine receptors, Lewis antigens, and act as autoantibodies [58,67-70]. In this regard, an example could be autoimmune gastritis, in which similarities of $\mathrm{H}^{+}, \mathrm{K}^{+}$-ATPase and bacterial epitopes may result in the production of antibodies against parietal cells, thereby suggesting that bacterial infection may be the trigger of an autoimmune mucosal inflammation resulting to mucosa atrophy in patients with chronic $H$. pylori gastritis [71]. Moreover, Lewis antigens seem to be upregulated in the conjunctival and corneal epithelia of glaucomatous eyes [72]; chemokine receptors are overexpressed in the conjunctival epithelium of patients with glaucoma [73]; Hsps are present in retinal fractions of glaucomatous eyes [74,75]; and the expression of HLA antigens on conjunctival epithelial cells are also present in glaucomatous eyes $[76,77]$.

The levels of the induced specific autoantibodies increase in the circulation of glaucoma patients. They may have access to the brain, due to disruption of the blood-brain barrier/blood-ocular barrier (BOB) and would then be capable of killing retinal cells. This might contribute to the development and/or progression of glaucoma $[33,34,63,64,78]$. Related data indicate that $H$. pylori-specific antibody levels are significantly increased in both serum and in the aqueous humor of subjects with POAG and PEG [34]. Moreover, the level of titers of anti-H. pylori antibody might reflect the severity of glaucomatous damage; the titer of anti-H. pylori $\mathrm{IgG}$ antibody is correlated with the degree of vertical cupping, thus possibly reflecting the severity of glaucomatous damage $[34,79,80]$. Due to the observed strong correlation between aqueous and serum IgG levels in POAG and PEG, it has been hypothesized that $H$. pylori antibodies circulating in the bloodstream may enter aqueous circulation due to BOB disruption and may reach levels that are possibly sufficient to impact the development and progression of glaucoma. It should be remembered that the cut-off value to determine the H. pylori-positive cases in aqueous humor is $4.76 \mathrm{U} / \mathrm{mL}$ [34]. 
In view of the aforementioned considerations, further relatively large-scale prospective studies are warranted to elucidate in depth the hypothetical role of anti-H. pylori antibody titer in the pathophysiology of aging-related glaucoma.

In the subgroup analysis of the present study (Table 2), the association between $H$. pylori infection and glaucoma remained significant for Eastern and Western populations. Nevertheless, heterogeneity was preserved, thus possibly reflecting H. pylori and host genetic polymorphisms. Relative studies in specific populations have revealed that polymorphisms of various molecules implicated in $H$. pylori infection were associated with the severity and progress of the inflammation. Genetic variations of interleukin- $1 \beta$, tumor necrosis factor- $\alpha$ and other cytokines, normally upregulated in $H$. pylori gastritis with a pro-inflammatory and anti-secretory role, have been associated with a potentially increased risk for peptic ulcer disease and gastric cancer development in European populations. Similarly, genetic sequences of immune cells' superficial and intracellular receptors have been incriminated for intense gastric inflammation, dysplasia and oncogenesis; rs11535889 polymorphism of Toll-like receptor-4 and rs718226 polymorphism of nucleotide-binding oligomerisation domain-like receptors (NOD)-2 have been found in different Chinese sub-populations thus predisposing to gastric cancer, whereas the E266K single nucleotide polymorphism of NOD1 was connected with intense inflammation in Korean patients [81]. Concerning the H. pylori virulence, two strains have been recognized with a geographical distribution. The Asian-type Cag-A strain seems to be more virulent than the respective Western-type H. pylori, thus possibly causing a more intense gastritis and increasing the risk of gastric cancer. Although in all Western countries the Western-type Cag-A strain predominates, in Asia there is a prompt heterogeneity. Strains of Middle East regions, India and Mongolia have the western CagA; China, Japan, Korea and Vietnam have the Asian CagA strain, whereas some regions, such as Thailand, have both Asian and western CagA strains [82,83]. As regards the glaucoma subtype, the association remained significant between $H$. pylori infection and POAG or NTG, but not PEG.

Another meta-analysis included 10 studies with 695 glaucoma patients and 1580 controls and reported similar results (OR: $2.08, I^{2}=63.6 \%$ ), although without clearly focusing on the potential impact of active H. pylori infection on glaucoma by estimation of virtual heterogeneity as well [18]. The studies added in the last five years $(n=5)$ did not change the positive association between $H$. pylori infection and glaucoma, and reinforce this relationship. It is striking that the association also remained robust for POAG or NTG, but not for PEG [18]. Future mechanistic research may shed light on this ambiguous association. Furthermore, other parameters with an established relationship to glaucoma (e.g., medications, family history, myopia, comorbidities, host genetic polymorphisms and $H$. pylori genotypes) [84] may be considered in future observational studies, to conduct multivariate analyses investigating $H$. pylori infection as a confounder of glaucoma.

From a pathogenetic point of view, potential links between H. pylori infection and glaucoma may include dysbiosis of the gastrointestinal microbiota and release of inflammatory cytokines, as well as chronic $H$. pylori infection and gastric inflammation that might trigger inducible release of nitric oxide synthase, nitric oxide (NO) production and formation of reactive nitrogen species, such as peroxynitrite [85]. The structural characteristics of these molecules may allow systematic diffusion and remote effects on the eye; high concentrations in the eye could promote nitrosative stress, mitochondrial damage through parthanatos (a DNA fragmenting chain reaction), neurotoxicity, optic nerve degeneration and apoptosis of retinal ganglionic cells. Furthermore, fluctuations in the severity of $H$. pylori-related gastritis may affect NO concentrations, thereby possibly modifying its vasoactive activity and contributing to unstable perfusion pressure in ocular arteries, transient ischemia and reperfusion damage, leading to increased intraocular pressure [85]. However, these speculations would have to be clarified by future research.

Finally, regarding the potential impact of $H$. pylori eradication on glaucoma parameters, a relative study reported that elimination of $H$. pylori could have effectively improve glaucoma parameters ( $p<0.001$ for intraocular pressure; $p \leq 0.01$ for visual field), thereby suggesting a possible casual relation between $H$. pylori infection and glaucoma [42]. Likewise, comparable results were recently 
reported after H. pylori eradication by others ( $p<0.005$ for intraocular pressure) [86] Since another study reported that the effect of $H$. pylori eradication in glaucoma therapy is not clear [87], therefore further large-scale prospective studies are needed to elucidate this issue.

The current meta-analysis has some limitations. The studies included were observational, so no causal relationship could be established. Moreover, methodological differences between the studies (e.g., H. pylori infection diagnosis, controls selection) add to the heterogeneity, thus affecting the synthesis of the studies included. Quality assessment commonly uses NOS, but its implementation is largely subjective. Furthermore, conference abstracts and other sources of grey literature were not considered for this systematic review. On the one hand, this increases the possibility of publication bias. Moreover, the quality of data in abstracts and grey literature is not peer reviewed in-depth; as they are included, the risk of low-quality data is increased. By selecting only English publications, a selection bias is also introduced. To avoid subjective bias, a sensitivity analysis was performed after excluding all studies of our group, and the results were essentially similar to the main analysis. Another methodological concern was the controls used in some studies, who were patients with cataract or anemia. It is known that H. pylori infection predisposes to anemia, and its eradication is accompanied by reversal of anemia [42]. It is possible, therefore, that these control groups had higher rates of $H$. pylori infection than the general population; however, the association between $H$. pylori infection and glaucoma remained robust in studies with anemic controls.

\section{Conclusions}

In conclusion, to our knowledge, this systematic review and meta-analysis shows, for the first time, a positive association between active $H$. pylori infection and glaucoma with null heterogeneity, which is also quantified by anti-H. pylori titers. As a novelty prevalence, these titers rise significantly with age, and are predominantly higher among individuals aged 65 years or older [88]. This meta-analysis warrants mechanistic studies to enlighten the possible links between the two disorders, and, importantly, clinical trials to investigate the possible effect of $H$. pylori eradication on glaucoma pathophysiology. Nevertheless, since glaucoma is a multifactorial disease, we do not expect the eradication of a single factor, H. pylori infection, will eliminate glaucoma, but perhaps just decrease its incidence.

Author Contributions: Conceptualization, M.D., J.K., A.P.; methodology, M.D., A.P., J.K., S.A.P.; software, A.P., M.D., P.B., validation, D.S.S., P.K., C.Z., P.B.; investigation, M.D., A.P., S.A.P., J.K.; resources M.D., D.S.S.; writing—original draft M.D., A.P., J.K., S.A.P.; writing—review and editing, M.D., A.P., S.A.P., C.Z., J.K., P.B.; visualization, M.D., D.S.S., C.Z., C.L.; supervision, J.K., C.L., P.K.; project administration, J.K., P.K. All authors have read and agreed to the published version of the manuscript.

Funding: This research received no external funding.

Conflicts of Interest: M.D. has received a travel grant from Gilead Sciences Switzerland Sàrl. The rest of the authors declare no conflict of interest.

$\begin{array}{ll}\text { Abbreviations } \\ \text { AD } & \text { Alzheimer's Disease } \\ \text { BOB } & \text { Blood-Ocular-Barrier } \\ \text { CI } & \text { Confidence Interval } \\ \text { Hsps } & \text { heat shock proteins } \\ \text { H. pylori } & \text { Helicobacter pylori } \\ \text { HLA } & \text { Human leukocyte antigens } \\ \text { IG } & \text { Immunoglobulin } \\ \text { NOD } & \text { Nucleotide-Binding Oligomerisation Domain } \\ \text { NTG } & \text { Normal Tension Glaucoma } \\ \text { POAG } & \text { Primary Open-Angle Glaucoma } \\ \text { PEG } & \text { Pseudo-Exfoliation Glaucoma } \\ \text { RUT } & \text { Rapid Urease Test } \\ \text { SD } & \text { Standard Deviation } \\ \text { WMD } & \text { Weighted Mean Differences }\end{array}$




\section{References}

1. Chmiela, M.; Karwowska, Z.; Gonciarz, W.; Allushi, B.; Staczek, P. Host pathogen interactions in Helicobacter pylori related gastric cancer. World J. Gastroenterol. 2017, 23, 1521-1540. [CrossRef] [PubMed]

2. Zamani, M.; Ebrahimtabar, F.; Zamani, V.; Miller, W.H.; Alizadeh-Navaei, R.; Shokri-Shirvani, J.; Derakhshan, M.H. Systematic review with meta-analysis: The worldwide prevalence of Helicobacter pylori infection. Aliment. Pharmacol. Ther. 2018, 47, 868-876. [CrossRef] [PubMed]

3. Gerges, S.E.; Alosh, T.K.; Khalil, S.H.; El Din, M.M.W. Relevance of Helicobacter pylori infection in Egyptian multiple sclerosis patients. Egypt. J. Neurol. Psychiatry Neurosurg. 2018, 54, 41. [CrossRef] [PubMed]

4. Kountouras, J.; Doulberis, M.; Papaefthymiou, A.; Polyzos, S.A.; Vardaka, E.; Tzivras, D.; Dardiotis, E.; Deretzi, G.; Giartza-Taxidou, E.; Grigoriadis, S.; et al. A perspective on risk factors for esophageal adenocarcinoma: Emphasis on Helicobacter pylori infection. Ann. N. Y. Acad. Sci. 2019, 1452, 12-17. [CrossRef]

5. Mentis, A.-F.A.; Boziki, M.; Grigoriadis, N.; Papavassiliou, A.G. Helicobacter pylori infection and gastric cancer biology: Tempering a double-edged sword. Cell. Mol. Life Sci. 2019, 76, 2477-2486. [CrossRef]

6. Crowe, S.E. Helicobacter pylori Infection. N. Engl. J. Med. 2019, 380, 1158-1165. [CrossRef]

7. Kuo, S.-H.; Cheng, A.-L. Helicobacter pylori and mucosa-associated lymphoid tissue: What's new. Hematol. Am. Soc. Hematol. Educ. Progr. 2013, 2013, 109-117. [CrossRef]

8. Romano, M.; Ricci, V.; Zarrilli, R. Mechanisms of Disease: Helicobacter pylori-related gastric carcinogenesis-Implications for chemoprevention. Nat. Clin. Pract. Gastroenterol. Hepatol. 2006, 3, 622-632. [CrossRef]

9. Stewart, O.A.; Wu, F.; Chen, Y. The role of gastric microbiota in gastric cancer. Gut Microbes 2020, 1-11. [CrossRef]

10. Ricci, V.; Giannouli, M.; Romano, M.; Zarrilli, R. Helicobacter pylori gamma-glutamyl transpeptidase and its pathogenic role. World J. Gastroenterol. 2014, 20, 630-638. [CrossRef]

11. Roubaud Baudron, C.; Franceschi, F.; Salles, N.; Gasbarrini, A. Extragastric Diseases and Helicobacter pylori. Helicobacter 2013, 18, 44-51. [CrossRef] [PubMed]

12. Franceschi, F.; Gasbarrini, A.; Polyzos, S.A.; Kountouras, J. Extragastric Diseases and Helicobacter pylori. Helicobacter 2015, 20, 40-46. [CrossRef] [PubMed]

13. Gravina, A.G.; Zagari, R.M.; De Musis, C.; Romano, L.; Loguercio, C.; Romano, M. Helicobacter pylori and extragastric diseases: A review. World J. Gastroenterol. 2018, 24, 3204-3221. [CrossRef] [PubMed]

14. Franceschi, F.; Tortora, A.; Gasbarrini, G.; Gasbarrini, A. Helicobacter pylori and Extragastric Diseases. Helicobacter 2014, 19, 52-58. [CrossRef] [PubMed]

15. Jonas, J.B.; Aung, T.; Bourne, R.R.; Bron, A.M.; Ritch, R.; Panda-Jonas, S. Glaucoma. Lancet (Lond. Engl.) 2017, 390, 2183-2193. [CrossRef]

16. Chou, T.-H.; Musada, G.R.; Romano, G.L.; Bolton, E.; Porciatti, V. Anesthetic Preconditioning as Endogenous Neuroprotection in Glaucoma. Int. J. Mol. Sci. 2018, 19, 237. [CrossRef]

17. Tang, Y.; Tan, J.; Zhou, X.; Li, X. Modified phacoemulsification plus goniosynechialysis compared with conventional surgery for cataract and glaucoma. Exp. Ther. Med. 2019, 1, 131-136. [CrossRef]

18. Zeng, J.; Liu, H.; Liu, X.; Ding, C.; Liuz, X.; Ding, C. The relationship between Helicobacter pylori infection and open-angle glaucoma: A meta-analysis. Investig. Ophthalmol. Vis. Sci. 2015, 56, 5238-5245. [CrossRef]

19. Kim, J.M.; Kim, S.H.; Park, K.H.; Han, S.Y.; Shim, H.S. Investigation of the association between Helicobacter pylori infection and normal tension glaucoma. Investig. Ophthalmol. Vis. Sci. 2011, 52, 665-668. [CrossRef]

20. Kountouras, J.; Zavos, C.; Deretzi, G. Primary open-angle glaucoma. N. Engl. J. Med. 2009, 360, $2679-2680$.

21. Zavos, C. Immuno-Gastroenterology: A New Multi-Disciplinary Journal. ImmunoGastroenterology 2013, 1, 1. [CrossRef]

22. Deshpande, N.; Lalitha, P.; Krishna das, S.R.; Jethani, J.; Pillai, R.M.; Robin, A. Karthik Helicobacter pylori IgG Antibodies in Aqueous Humor and Serum of Subjects With Primary Open Angle and Pseudo-exfoliation Glaucoma in a South Indian Population. J. Glaucoma 2008, 17, 605-610. [CrossRef] [PubMed]

23. Kurtz, S.; Regenbogen, M.; Goldiner, I.; Horowitz, N.; Moshkowitz, M. No Association Between Helicobacter pylori Infection or CagA-bearing Strains and Glaucoma. J. Glaucoma 2008, 17, 223-226. [CrossRef] [PubMed]

24. Galloway, P.H.; Warner, S.J.; Morshed, M.G.; Mikelberg, F.S. Helicobacter pylori infection and the risk for open-angle glaucoma. Ophthalmology 2003, 110, 922-925. [CrossRef] 
25. Moran, A.P.; Prendergast, M.M. Molecular mimicry in Campylobacter jejuni and Helicobacter pylori lipopolysaccharides: Contribution of gastrointestinal infections to autoimmunity. J. Autoimmun. 2001, 16, 241-256. [CrossRef]

26. Kountouras, J.; Deretzi, G.; Zavos, C.; Karatzoglou, P.; Touloumis, L.; Nicolaides, T.; Chatzopoulos, D.; Venizelos, I. Association between Helicobacter pylori infection and acute inflammatory demyelinating polyradiculoneuropathy. Eur. J. Neurol. 2005, 12, 139-143. [CrossRef]

27. Kountouras, J.; Deretzi, G.; Grigoriadis, N.; Zavos, C.; Boziki, M.; Gavalas, E.; Katsinelos, P.; Tzilves, D.; Giouleme, O.; Lazaraki, G. Guillain-Barré syndrome. Lancet Neurol. 2008, 7, 1080-1081; author reply 1083-1085. [CrossRef]

28. Kountouras, J.; Zavos, C.; Chatzopoulos, D. A concept on the role of Helicobacter pylori infection in autoimmune pancreatitis. J. Cell. Mol. Med. 2005, 9, 196-207. [CrossRef]

29. Frulloni, L.; Lunardi, C.; Simone, R.; Dolcino, M.; Scattolini, C.; Falconi, M.; Benini, L.; Vantini, I.; Corrocher, R.; Puccetti, A. Identification of a Novel Antibody Associated with Autoimmune Pancreatitis. N. Engl. J. Med. 2009, 361, 2135-2142. [CrossRef]

30. Guarneri, F.; Guarneri, C.; Benvenga, S. Helicobacter pylori and autoimmune pancreatitis: Role of carbonic anhydrase via molecular mimicry? J. Cell. Mol. Med. 2005, 9, 741-744. [CrossRef]

31. Romano, C.; Barrett, D.A.; Li, Z.; Pestronk, A.; Wax, M.B. Anti-rhodopsin antibodies in sera from patients with normal-pressure glaucoma. Investig. Ophthalmol. Vis. Sci. 1995, 36, 1968-1975.

32. Doulberis, M.; Kotronis, G.; Thomann, R.; Polyzos, S.A.; Boziki, M.; Gialamprinou, D.; Deretzi, G.; Katsinelos, P.; Kountouras, J. Impact of helicobacter pylori on alzheimer's disease: What do we know so far? Helicobacter 2017. [CrossRef]

33. Kountouras, J. Helicobacter pylori: An intruder involved in conspiring glaucomatous neuropathy. Br. J. Ophthalmol. 2009, 93, 1413-1415. [CrossRef] [PubMed]

34. Kountouras, J.; Mylopoulos, N.; Konstas, A.G.P.A.G.P.; Zavos, C.; Chatzopoulos, D.; Boukla, A. Increased levels of Helicobacter pylori IgG antibodies in aqueous humor of patients with primary open-angle and exfoliation glaucoma. Graefe's Arch. Clin. Exp. Ophthalmol. 2003, 241, 884-890. [CrossRef] [PubMed]

35. Kountouras, J.; Tsolaki, M.; Gavalas, E.; Boziki, M.; Zavos, C.; Karatzoglou, P.; Chatzopoulos, D.; Venizelos, I. Relationship between Helicobacter pylori infection and Alzheimer disease. Neurology 2006, 66, 938-940. [CrossRef]

36. Tu, H.; Sun, L.; Dong, X.; Gong, Y.; Xu, Q.; Jing, J.; Yuan, Y. Serum anti-Helicobacter pylori immunoglobulin G titer correlates with grade of histological gastritis, mucosal bacterial density, and levels of serum biomarkers. Scand. J. Gastroenterol. 2014, 49, 259-266. [CrossRef]

37. Chung, H.A.; Lee, S.-Y.; Moon, H.W.; Kim, J.H.; Sung, I.-K.; Park, H.S.; Shim, C.S.; Han, H.S. Does the antibody production ability affect the serum anti-Helicobacter pylori IgG titer? World J. Gastrointest. Pathophysiol. 2016, 7, 288-295. [CrossRef]

38. Stroup, D.F.; Berlin, J.A.; Morton, S.C.; Olkin, I.; Williamson, G.D.R.D. MOOSE Guidelines for Meta-Analyses and Systematic Reviews of Observational Studies. Jama 2000, 283, 2008-2012.

39. Moher, D.; Shamseer, L.; Clarke, M.; Ghersi, D.; Liberati, A.; Petticrew, M.; Shekelle, P.; Stewart, L.A. PRISMA-P Group Preferred reporting items for systematic review and meta-analysis protocols (PRISMA-P) 2015 statement. Syst. Rev. 2015, 4, 1. [CrossRef]

40. Kim, S.Y.; Park, J.E.; Lee, Y.J.; Seo, H.-J.; Sheen, S.-S.; Hahn, S.; Jang, B.-H.; Son, H.-J. Testing a tool for assessing the risk of bias for nonrandomized studies showed moderate reliability and promising validity. J. Clin. Epidemiol. 2013, 66, 408-414. [CrossRef]

41. Hong, Y.; Zhang, C.; Duan, L.; Wang, W. Relationship between Helicobacter pylori infection and open angle glaucoma in China. Asian J. Ophthalmol. 2017, 9, 205-208.

42. Kountouras, J.; Mylopoulos, N.; Chatzopoulos, D.; Zavos, C.; Boura, P.; Konstas, A.G.P.; Venizelos, J. Eradication of Helicobacter pylori may be beneficial in the management of chronic open-angle glaucoma. Arch. Intern. Med. 2002, 162, 1237-1244. [CrossRef] [PubMed]

43. Ubani, U.A.; Timothy, C.O.; Ihesiulor, G.C. Assessment of Helicobacter Pylori in Glaucoma Disease in Abia State of Nigeria. Int. Educ. Appl. Sci. Res. J. 2017, 2, 7-12.

44. Ozturk, F.; Kurt, E.; Ubeyt Inan, U.; Samet Ermis, S.; Cetinkaya, Z.; Altindis, M. Is there a relationship between glaucoma and Helicobacter pylori? Afr. J. Microbiol. Res. 2009, 3, 560-564. 
45. Samarai, V.; Sharifi, N.; Nateghi, S. Association between helicobacter pylori infection and primary open angle glaucoma. Glob. J. Health Sci. 2014, 6, 13-17. [CrossRef]

46. Sultana, S.; Khan, N.; Ghosh, C.K.; Saleh, A.A.; Islam, M.S. Association between Helicobacter pylori infection and primary open-angle glaucoma. Bangabandhu Sheikh Mujib Med. Univ. J. 2019, 12, 25-28. [CrossRef]

47. Tsolaki, F.; Kountouras, J.; Topouzis, F.; Tsolaki, M. Helicobacter pylori infection, dementia and primary open-angle glaucoma: Are they connected? BMC Ophthalmol. 2015, 15, 24. [CrossRef]

48. Tuzcu, E.A.; Aydogan, F.; Motor, V.K.; Ilhan, O.; Daglioglu, M.C.; Coskun, M.; Parlakfikirer, N.; Keskin, U. Investigation of the association between glaucoma and Helicobacter pylori infection using the 14C-urea breath test. Arq. Bras. Oftalmol. 2015, 78, 229-231. [CrossRef]

49. Zavos, C.; Kountouras, J.; Sakkias, G.; Venizelos, I.; Deretzi, G.; Arapoglou, S. Histological presence of Helicobacter pylori bacteria in the trabeculum and iris of patients with primary open-angle glaucoma. Ophthalmic Res. 2012, 47, 150-156. [CrossRef]

50. Abrishami, M.; Kargozar, A.; Rashed, T.; Shoeibi, N.; Attaranzadeh, A. Association of Helicobacter Pylori Infection with Primary Open Angle Glaucoma. Bina J. Ophthalmol. 2007, 12, 289-293.

51. Kountouras, J.; Mylopoulos, N.; Boura, P.; Bessas, C.; Chatzopoulos, D.; Venizelos, J.; Zavos, C. Relationship between Helicobacter pylori infection and glaucoma. Ophthalmology 2001, 108, 599-604.

52. Noche, C.D.; Njajou, O.; Etoa, F.X. No Association between CagA- and VacA-Positive Strains of Helicobacter pylori and Primary Open-Angle Glaucoma: A Case-Control Study. Ophthalmol. Eye Dis. 2016, 8, 1-4. [CrossRef]

53. Pezzullo, L.; Streatfeild, J.; Simkiss, P.; Shickle, D. The economic impact of sight loss and blindness in the UK adult population. BMC Health Serv. Res. 2018, 18, 63. [CrossRef] [PubMed]

54. Yang, E.; Al-Mugheiry, T.S.; Normando, E.M.; Cordeiro, M.F. Real-Time Imaging of Retinal Cell Apoptosis by Confocal Scanning Laser Ophthalmoscopy and Its Role in Glaucoma. Front. Neurol. 2018, 9, 338. [CrossRef] [PubMed]

55. Sabbagh, P.; Javanian, M.; Koppolu, V.; Vasigala, V.R.; Ebrahimpour, S. Helicobacter pylori infection in children: An overview of diagnostic methods. Eur. J. Clin. Microbiol. Infect. Dis. 2019, 38, 1035-1045. [CrossRef]

56. Tian, X.-Y.; Zhu, H.; Zhao, J.; She, Q.; Zhang, G.-X. Diagnostic Performance of Urea Breath Test, Rapid Urea Test, and Histology for Helicobacter pylori Infection in Patients with Partial Gastrectomy. J. Clin. Gastroenterol. 2012, 46, 285-292. [CrossRef]

57. Malfertheiner, P.; Megraud, F.; O’Morain, C.A.; Gisbert, J.P.; Kuipers, E.J.; Axon, A.T.; Bazzoli, F.; Gasbarrini, A.; Atherton, J.; Graham, D.Y.; et al. Management of Helicobacter pylori infection-The Maastricht V/Florence Consensus Report. Gut 2017, 66, 6-30. [CrossRef]

58. Chmiela, M.; Gonciarz, W. Molecular mimicry in Helicobacter pylori infections. World J. Gastroenterol. 2017, 23, 3964. [CrossRef]

59. Saccà, S.C.; Vagge, A.; Pulliero, A.; Izzotti, A. Helicobacter pylori Infection and Eye Diseases. Medicine (Baltim.) 2014, 93, e216. [CrossRef]

60. Unterlauft, J.D.; Böhm, M.R.R. Rolle des alternden visuellen Systems bei Glaukomen. Der Ophthalmol. 2017, 114, 108-113. [CrossRef]

61. Day, A.L.; Singh, J.A. Cardiovascular Disease Risk in Older Adults and Elderly Patients with Rheumatoid Arthritis: What Role Can Disease-Modifying Antirheumatic Drugs Play in Cardiovascular Risk Reduction? Drugs Aging 2019, 36, 493-510. [CrossRef]

62. Castelo-Branco, C.; Soveral, I. The immune system and aging: A review. Gynecol. Endocrinol. 2014, 30, 16-22. [CrossRef] [PubMed]

63. Tezel, G.; Edward, D.P.; Wax, M.B. Serum Autoantibodies to Optic Nerve Head Glycosaminoglycans in Patients with Glaucoma. Arch. Ophthalmol. 1999, 117, 917-924. [CrossRef] [PubMed]

64. Wax, M.B.; Tezel, G.; Saito, I.; Gupta, R.S.; Harley, J.B.; Li, Z.; Romano, C. Anti-Ro/SS-A positivity and heat shock protein antibodies in patients with normal-pressure glaucoma. Am. J. Ophthalmol. 1998, 125, 145-157. [CrossRef]

65. Kornberg, A.J.; Pestronk, A. Immune-mediated neuropathies. Curr. Opin. Neurol. 1993, 6, 681-687. [CrossRef] [PubMed] 
66. Cartwright, M.J. Immune-Related Disease and Normal-Tension Glaucoma. Arch. Ophthalmol. 1992, 110, 500. [CrossRef] [PubMed]

67. Jafarzadeh, A.; Nemati, M.; Jafarzadeh, S. The important role played by chemokines influence the clinical outcome of Helicobacter pylori infection. Life Sci. 2019, 231, 116688. [CrossRef]

68. Lang, B.J.; Gorrell, R.J.; Tafreshi, M.; Hatakeyama, M.; Kwok, T.; Price, J.T. The Helicobacter pylori cytotoxin CagA is essential for suppressing host heat shock protein expression. Cell Stress Chaperones 2016, 21, 523-533. [CrossRef]

69. Duarte, H.; Freitas, D.; Gomes, C.; Gomes, J.; Magalhães, A.; Reis, C. Mucin-Type O-Glycosylation in Gastric Carcinogenesis. Biomolecules 2016, 6, 33. [CrossRef]

70. Gönen, S.; Sari, S.; Kandur, Y.; Dalgiç, B.; Söylemezoğlu, O. Evaluation of human leukocyte antigen class I and II antigens in Helicobacter pylori-positive pediatric patients with active gastritis and duodenal ulcer. Arq. Gastroenterol. 2017, 54, 297-299. [CrossRef]

71. Claeys, D.; Faller, G.; Appelmelk, B.J.; Negrini, R.; Kirchner, T. The gastric $\mathrm{H}^{+}, \mathrm{K}^{+}$-ATPase is a major autoantigen in chronic Helicobacter pylori gastritis with body mucosa atrophy. Gastroenterology 1998, 115, 340-347. [CrossRef]

72. Terraciano, A.J.; Wang, N.; Schuman, J.; Haffner, G.; Panjwani, N.; Zhao, Z.; Yang, Z. Sialyl Lewis X, Lewis $\mathrm{X}$, and $\mathrm{N}$-acetyllactosamine expression on normal and glaucomatous eyes. Curr. Eye Res. 1999, 18, 73-78. [CrossRef] [PubMed]

73. Liang, H.; Baudouin, C.; Hamard, P.; Creuzot-Garcher, C.; Warnet, J.-M.; Brignole-Baudouin, F. [Activation of TH1/TH2 pathways detected through the expression of CCR4 and CCR5 on the ocular surface of glaucomatous patients treated over the long term]. J. Fr. Ophtalmol. 2006, 29, 121-126. [CrossRef]

74. Tsai, T.; Reinehr, S.; Maliha, A.; Joachim, S. Degeneration and Possible Protection in Glaucoma. Front. Neurosci. 2019, 13, 931. [CrossRef] [PubMed]

75. Tezel, G.; Seigel, G.M.; Wax, M.B. Autoantibodies to small heat shock proteins in glaucoma. Investig. Ophthalmol. Vis. Sci. 1998, 39, 2277-2287.

76. Cvenkel, B.; Kopitar, A.N.; Ihan, A. Correlation Between Filtering Bleb Morphology, Expression of Inflammatory Marker HLA-DR by Ocular Surface, and Outcome of Trabeculectomy. J. Glaucoma 2013, 22, 15-20. [CrossRef]

77. David, R.; Maier, G.; Baumgarten, I.; Abrahams, C. HLA antigens in glaucoma and ocular hypertension. Br. J. Ophthalmol. 1979, 63, 293-296. [CrossRef]

78. Kountouras, J.; Boziki, M.; Polyzos, S.A.; Katsinelos, P.; Gavalas, E.; Zeglinas, C.; Tzivras, D.; Romiopoulos, I.; Giorgakis, N.; Anastasiadou, K.; et al. The emerging role of helicobacter pylori-induced metabolic gastrointestinal dysmotility and neurodegeneration. Curr. Mol. Med. 2017, 17, 389-404. [CrossRef]

79. Sakimoto, S.; Okazaki, T.; Usui, S.; Ishibashi, T.; Oura, Y.; Nishida, K.; Miki, A.; Kawasaki, R.; Matsushita, K.; Sakaguchi, H.; et al. Cross-Sectional Imaging Analysis of Epiretinal Membrane Involvement in Unilateral Open-Angle Glaucoma Severity. Investig. Opthalmol. Vis. Sci. 2018, 59, 5745. [CrossRef]

80. Cui, Q.N.; Ramakrishnan, M.S.; Gudiseva, H.V.; Collins, D.W.; Pistilli, M.; Lee, R.; Chavali, V.M.; Lehman, A.; Addis, V.M.; O'Brien, J.M. Mitochondrial haplogroup L1c2 is associated with increased disease severity in African American patients with primary open-angle glaucoma. J. Clin. Exp. Ophthalmol. 2019, 10, 799.

81. Clyne, M.; Rowland, M. The Role of Host Genetic Polymorphisms in Helicobacter Pylori Mediated Disease Outcome; Springer Nature Switzerland AG: Basel, Switzerland, 2019; pp. 151-172.

82. Suzuki, H.; Mori, H. Different Pathophysiology of Gastritis between East and West? An Asian Perspective. Inflamm. Intest. Dis. 2016, 1, 123-128. [CrossRef] [PubMed]

83. Tserentogtokh, T.; Gantuya, B.; Subsomwong, P.; Oyuntsetseg, K.; Bolor, D.; Erdene-Ochir, Y.; Azzaya, D.; Davaadorj, D.; Uchida, T.; Matsuhisa, T.; et al. Western-Type Helicobacter pylori CagA are the Most Frequent Type in Mongolian Patients. Cancers 2019, 11, 725. [CrossRef] [PubMed]

84. McMonnies, C.W. Glaucoma history and risk factors. J. Optom. 2017, 10, 71-78. [CrossRef] [PubMed]

85. Papaefthymiou, A.; Doulberis, M.; Katsinelos, P.; Liatsos, C.; Polyzos, S.A.; Kotronis, G.; Papanikolaou, K.; Kountouras, J. Impact of nitric oxide's bidirectional role on glaucoma: Focus on Helicobacter pylori-Related nitrosative stress. Ann. N. Y. Acad. Sci. 2019, 1465, 10-28. [CrossRef] [PubMed]

86. Ala, S.; Maleki, I.; Sanjari Araghi, A.; Sahebnasagh, A.; Shahraki, A. Helicobacter pylori eradication in the management of glaucoma. Casp. J. Intern. Med. 2020, 11, 143-149. 
87. Chen, H.-Y.; Lin, C.-L.; Chen, W.-C.; Kao, C.-H. Does Helicobacter pylori Eradication Reduce the Risk of Open Angle Glaucoma in Patients with Peptic Ulcer Disease? Medicine (Baltim.) 2015, 94, e1578. [CrossRef]

88. Jin, S.; Trope, G.E.; Buys, Y.M.; Badley, E.M.; Thavorn, K.; Yan, P.; Nithianandan, H.; Jin, Y.-P. Reduced social participation among seniors with self-reported visual impairment and glaucoma. PLoS ONE 2019, 14, e0218540. [CrossRef] 